\title{
ANALISIS DETERMINAN EKSPOR PROVINSI SUMATERA UTARA: PENDEKATAN GRAVITY MODEL
}

\author{
Efori Telaumbanua \\ ProdiPascasarjana Ilmu Ekonomi, Universitas Negeri Medan \\ Telp. 081396982006, email: efo wise@yahoo.com
}

\begin{abstract}
Export Growth has been being one of important component in enhancing of economic growth of North Sumatera Province. During 2005-2010, the average growth of export rate of North Sumatera Province is 16,5 percent per year with 5,23 percent per year the average of it's contribution to growth. The aim of this research is to detect the factors which affect the enhancement of export rate of North Sumatera Province during 2005-2010. With augmented gravity model approach, this research analyzes the effect of gross domestic product percapita rate and the population of each trading partner countries, geographical distance between North Sumatera Province and every trading partner countries, foreig $n$ direct investment and real effective exchange rate of North Sumatera Province, to the export rate of North Sumatera Province to every trading countries, such as United States of America, Netherland, China, India, Italy, Japan, Malaysia, Egypt, Singapore, and Ukraine. By using random effect model in pooled data processing, the result of this research describes that the gross domestic product percapita and the population of each trading partner countries affect positively and significantly to the export rate of North Sumatera Prov ince. As well as fo reign direct investment rate and real effective exchange rate of North Sumatera Province show the positive and significant effect. Whereas, geographical distance as the trade barrier, correlate negatively and significantly to the export rate of North Sumatera Province.
\end{abstract}

Keywords:Export rate, gravity model approach, export destination country

\section{PENDAHULUAN}

ewasa ini pertumbuhan nilai ekspor merupakan engine of development dalam mendukung pertumbuhan ekonomi suatu negara.Peningkatan pertumbuhan ekspor di Indonesia merupakan upaya nyata pemerintah sejak pertengahan 1980-an seiring dengan berubahnya strategi industrialisasi dari penekanan pada industri substitusi impor ke industri promosi ekspor. Pergeseran ini terjadi setelah pemerintah mengeluarkan serangkaian 
kebijakan dan deregulasi di bidang ekspor, sehingga memungkinkan produsen untuk meningkatkan ekspor, khususny a ekspor nonmigas.

Kegiatan menggenjot nilai ekspor tidak saja dilakukan oleh pemerintah pusat, tetapi juga oleh masing-masing daerah, yang bertujuan untuk meningkatkan pertumbuhan ekonomi yang semakin tinggi, termasuk Provinsi Sumatera Utara. Seperti terlihat pada Tabel 1, dalam kurun waktu 2001-2010, ekspor sebagai salah satu komponen dalam struktur PDRB Provinsi Sumatera Utara terlihat tumbuh positif, kecuali pada tahun 2009 sebagai imbas dari krisis global di akhir 2008. Selama kurun waktu 2001-2010, kontribusi ekspor terhadap PDRB Provinsi Sumatera Utara tumbuh rata-rata 7,14 persen per tahun, melebihi pertumbuhan rata-rata PDRB dalam kurun waktu yang sama, yakni sebesar 5,55 persen per tahun.

Tabel 1. Pertumbuhan Ekonomi Provinsi Sumatera Utara Menurut Penggunaan 2001-2010 (Persen)

\begin{tabular}{lcccccccccc}
\hline \multicolumn{1}{c}{ Jenis } & \multicolumn{10}{c}{ T a h u n } \\
\cline { 2 - 11 } Penggunaan & $\mathbf{2 0 0 1}$ & $\mathbf{2 0 0 2}$ & $\mathbf{2 0 0 3}$ & $\mathbf{2 0 0 4}$ & $\mathbf{2 0 0 5}$ & $\mathbf{2 0 0 6}$ & $\mathbf{2 0 0 7}$ & $\mathbf{2 0 0 8}$ & $\mathbf{2 0 0 9}$ & $\mathbf{2 0 1 0}$ \\
Konsumsi & 2,22 & 4,85 & 6,50 & 4,73 & 6,68 & 8,64 & 9,53 & 6,95 & 8,07 & 8,58 \\
Investasi & $-2,40$ & 1,80 & $-7,14$ & $-12,51$ & 16,21 & 17,32 & 29,45 & 24,32 & 4,62 & 4,78 \\
Ekspor & 9,92 & 5,18 & 2,39 & 22,56 & 6,48 & 2,84 & 2,10 & 10,60 & $-0,95$ & 10,29 \\
Impor & 4,78 & 4,53 & $-2,76$ & 22,68 & 14,75 & 10,65 & 15,42 & 22,75 & 2,56 & 14,44 \\
\hline \multicolumn{1}{c}{ PDRB } & $\mathbf{3 , 9 8}$ & $\mathbf{4 , 5 6}$ & $\mathbf{4 , 8 1}$ & $\mathbf{5 , 7 4}$ & $\mathbf{5 , 4 8}$ & $\mathbf{6 , 1 8}$ & $\mathbf{6 , 9 0}$ & $\mathbf{6 , 3 9}$ & $\mathbf{5 , 0 7}$ & $\mathbf{6 , 3 7}$ \\
\hline
\end{tabular}

Sumber : BPS (berbag ai tahun terbitan, diolah)

Dalam kurun waktu 2001-2005, ekspor Provinsi Sumatera Utara tumbuh fluktuatif, namun sejak tahun 2005 sampai dengan tahun 2010, pertumbuhan ekspor menunjukkan trend yang semakin meningkat, kecuali pada tahun 2009 yang turun drastis sekitar 30,25 persen dibandingkan tahun 2008, sebagai imbas dari krisis finansial global sejak pertengahan 2008. Pertumbuhan ekspor Provinsi Sumatera Utara yang semakin meningkat dalam kurun waktu 2005-2010, ditunjukkan pada Gambar 1. 


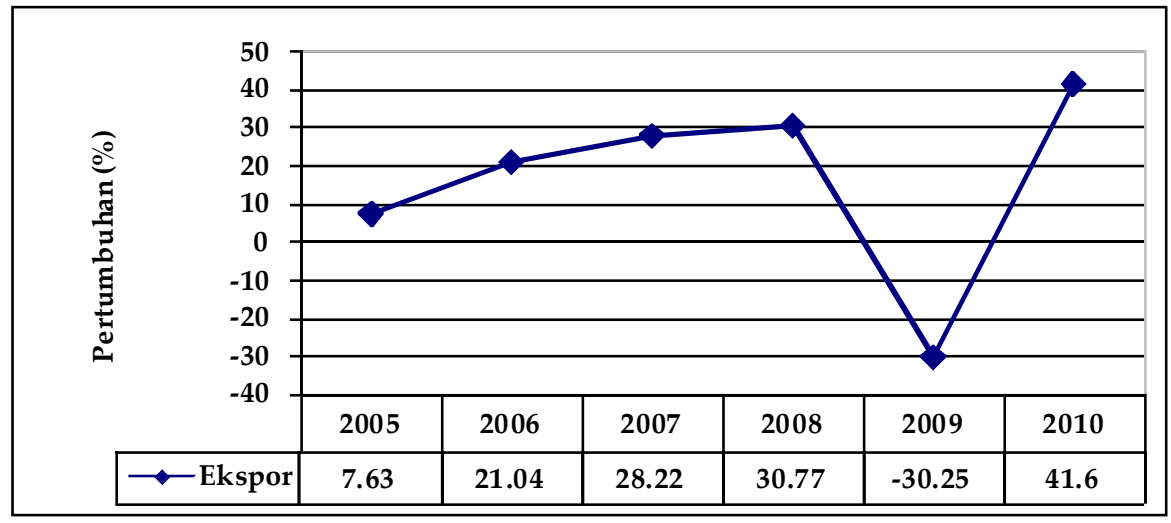

Sumber : BPS (berbag ai tahun terbitan, diolah)

Gambar 1. Pertumbuhan Nilai Ekspor Nonmigas Provinsi Sumatera Utara Tahun 2005 - 2010

Dari sisi mitra dagang, negara tujuan utama ekspor Provinsi Sumatera Utara antara lain adalah India, Jepang, Cina, Amerika Serikat, Belanda, Singapura, Malaysia, Italia, Mesir, dan Ukraina. Nilai ekspor Provinsi Sumatera Utara ke masing-masing negara tersebut ditunjukkan pada Tabel 2.

Tabel 2. Nilai Ekspor Sumatera Utara ke Negara Tujuan Utama (000 US\$)Tahun 2005-2010

\begin{tabular}{|c|c|c|c|c|c|c|c|}
\hline \multirow{2}{*}{$\begin{array}{l}\text { Negara } \\
\text { Tujuan } \\
\text { Utama } \\
\text { Ekspor }\end{array}$} & \multicolumn{6}{|c|}{ Tahun } & \multirow[b]{2}{*}{ Total } \\
\hline & 2005 & 2006 & 2007 & 2008 & 2009 & 2010 & \\
\hline 1 & 2 & 3 & 4 & 5 & 6 & 7 & 8 \\
\hline India & 332.677 & 433.554 & 907.379 & 1.540 .773 & 1.087 .285 & 1.528 .616 & 5.830 .284 \\
\hline Jepang & 582.077 & 894.044 & 949.637 & 1.053 .721 & 623.059 & 1.038 .553 & 5.141 .091 \\
\hline Cina & 377.795 & 545.975 & 620.430 & 718.975 & 527.512 & 811.678 & 3.602 .365 \\
\hline A $S$ & 454.186 & 461.230 & 518.761 & 612.452 & 516.318 & 661.003 & 3.223 .950 \\
\hline Belanda & 349.460 & 326.089 & 422.717 & 427.877 & 249.564 & 435.009 & 2.210 .716 \\
\hline Sing apura & 207.383 & 228.967 & 290.047 & 300.892 & 317.744 & 363.172 & 1.708 .205 \\
\hline Malaysia & 162.836 & 216.475 & 219.498 & 381.426 & 262.279 & 316.621 & 1.559 .135 \\
\hline Italia & 102.334 & 111.663 & 132.992 & 243.897 & 174.600 & 210.883 & 976.369 \\
\hline Mesir & 54.823 & 68.964 & 159.031 & 253.475 & 210.336 & 210.535 & 957.164 \\
\hline Ukraina & 70.791 & 39.610 & 63.828 & 129.660 & 168.831 & 250.192 & 722.912 \\
\hline
\end{tabular}

Sumber: BPS (berbagai tahun terbitan)

Dari Tabel 2 di atas, terlihat bahwa dalam kurun waktu enam tahun terakhir, nilai terbesar dari ekspor Provinsi Sumatera Utara tertuju kepada empat negara yaitu

QE Journal |Vol.02 - No.02 - 37 
India, Jepang, Cina, dan Amerika Serikat. Hal ini karena keempat negara tersebut memiliki jumlah populasi dan sekaligus Gross Domestic Product (GDP) yang lebih besar dibandingkan negara tujuan lainnya.

Sukirno (2006), menjelaskan bahwa impor suatu negara ditentukan oleh pendapatan masyarakat suatu negara (GDP negara importir). Semakin tinggi pendapatan masyarakat maka semakin tinggi impor yang akan mereka lakukan. Oleh karena itu, fungsi impor sangat berhubungan dengan pendapatan nasional.Untuk menunjukkan daya beli masyarakat dari suatu negara dapat dilihat dari nilai pendapatan per kapita atau GDP per kapita, yang merupakan hasil pembagian GDP suatu negara dengan jumlah penduduk negara tersebut. Menurut Hoftyzer (1984), semakin tinggi pendapatan per kapita suatu negara maka semakin tinggi pula kemampuannya dalam melakukan perdagangan dengan negara lain, khususnya kemampuan membiayai impornya.

Sementara itu, jumlah populasi negara importir menunjukkan besarnya potensi pasar barang ekspor dari negara eksportir. Semakin besar populasi negara importir, maka permintaan negara tersebut akan barang impor juga semakin besar.

Bertolak dari kenyataan-kenyataan tersebut, menarik untuk meneliti pola hubungan perdagangan antara Provinsi Sumatera Utara dengan beberapa negara tujuan utama ekspornya. Salah satu pendekatan untuk memprediksi hubungan perdagangan bilateral adalah gravity model, yang didasarkan atas teori Sir Isaac Newton tentang gravitasi pada tahun 1687 tentang gaya tarik-menarik antara dua benda, yang kemudian pada tahun 1962 Jan Tinbergen mengusulkan bahwa kurang lebih bentuk fungsional yang sama dapat diterapkan untuk arus perdagangan internasional.

Menurut Head (2003), model gravitasi sebenarnya merupakan bentuk yang lebih sederhana dari penggambaran kekuatan permintaan dan penawaran pasar. Jika negara ${ }^{i}$ adalah negara asal, maka ${ }^{M_{i}}$ merupakanjumlah total penawaran negara $i_{\text {kesemua pelanggan. Sementara }}{ }^{M_{j}}$ merupakan jumlah total permintaan negara

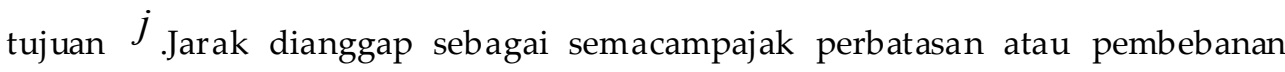
biaya perdagangan, yang mengakibatkan keseimbangan arus perdagangan lebih rendah. Dalam hal ini, persamaan gravitasi dapat ditulis:

$$
F_{i j}=R_{j} \frac{M_{i}^{\alpha} M_{j}^{\beta}}{D_{i j}^{\theta}}
$$

atau

$$
\ln F_{i j}=\alpha \ln M_{i}+\beta \ln M_{j}-\theta \ln D_{i j}+\rho \ln R_{j}
$$

QE Journal | Vol.02 - No.02 - 38 
Variabel $R_{j}$ (remotenes) adalah variabel yang bernilai konstan sehingga merupakan intercept dari suatu persamaan. Variabel ini merupakan ukuran substitusi dari negara importir, di mana semakin tinggi nilai variabel $R_{j}$, maka semakin banyak negara tersebut melakukan impor.

Krugman (1991) mempertimbangkan, bahwa jarak dua mitra dagang menjadi determinan penting pola perdagangan secara geografis,karena jarak akan meningkatkan biaya transportasi, sehingga secara teori ekonomi, jarak berhubungan negatif dengan ekspor.

Berdasarkan uraian di atas, variabel GDP dan jarak, yang merupakan variabel dasar dari gravity model, tidak cukup dapat menjelaskan pola hubungan perdagangan dimaksud. Oleh karena itu, pengaruh dari beberapa variabel lain perlu ditambahkan, sehingga model yang digunakan adalah augmented gravity model. Menurut Samuelson (1995), selain GDP, volume dan nilai ekspor dipengaruhi oleh harga relatif suatu komoditi di pasar internasional, yang berkaitan erat dengan nilai tukar mata uang.

Tambunan (2000), menjelaskan bahwa untuk mengukur tingkat daya saing ekspor suatu negara dalam perdagangan internasional, digunakan nilai tukar efektif riil atau real effective exchange rate (REER). REER menunjukkan daya beli relatif dari output domestik oleh sejumlah negara mitra dagang suatu negara. REER merupakan hasil kali antara nilai tukar nominal dengan rasio indeks harga di luar negeri dan di domestik.REER dapat ditentukan dengan formula berikut:

$$
R E E R_{t}=N E E R_{t} \frac{C P I_{t}^{\text {foreign }}}{C P I_{t}^{\text {domestic }}}
$$

di mana $R E E R_{t}$ adalah nilai tukar efektif riil suatu negara terhadap sekumpulan nilai mata uang negara-negara mitra dagangnya; $C P I_{t}^{\text {foreign }}$ adalah indeks harga konsumen negara-negara mitra dagang; $C P I_{t}^{\text {domestic }}$ adalah indeks harga konsumen domestik; dan $N E E R_{t}$ adalah nilai tukar efektif nominal negara tersebut. Jika nilai $R E E R_{t}$ naik maka hal itu mencerminkan bahwa harga barang-barang domestik suatu negara relatif lebih murah dibandingkan dengan harga barangbarang luar negeri, sehingga mengakibatkan peningkatan ekspor negara tersebut. Sebaliknya, jika $R E E R_{t}$ rendah maka hal tersebut menunjukkan bahwa harga barang-barang domestik suatu negara relatif lebih mahal dibandingkan harga barang-barang luar negeri, sehingga akan menurunkan ekspor negara tersebut. Dengan demikian, maka $R E E R_{t}$ berhubungan positif dengan ekspor suatu negara.

QE Journal |Vol.02 - No.02 - 39 
Selain beberapa variabel di atas, peningkatan nilai ekspor Sumatera Utara kemungkinan tidak terlepas dari pertumbuhan investasi, khususnya investasi asing langsung (FDI $=$ foreign direct investment) di Provinsi Sumatera Utara. Realisasi nilai FDI (PMA = Penanaman Modal Asing) di Sumatera Utara dalam kurun waktu enam tahun terakhir, ditunjukkan pada Tabel 3 berikut.

Tabel 3. Realisasi Nilai PMA di Sumatera Utara 2005-2010

\begin{tabular}{ccc}
\hline Tahun & Nilai PMA (US\$.000) & Pertumbuhan (\%) \\
$\mathbf{1}$ & $\mathbf{2}$ & $\mathbf{3}$ \\
\hline 2005 & & $-47,69$ \\
2006 & $52.669,55$ & 2,82 \\
2007 & $54.156,31$ & 509,81 \\
2008 & $330.250,53$ & $-22,73$ \\
2009 & $255.176,02$ & 268,49 \\
2010 & $940.296,46$ & $-69,09$ \\
\hline
\end{tabular}

Sumber : BPS (2011)

Dari data di atas, terlihat bahwa pertumbuhan investasi asing langsung di Provinsi Sumatera Utara berfluktuatif, namun secara keseluruhan memiliki pertumbuhan positif rata-rata 106,935 persen. Pertumbuhan yang cukup signifikan tersebut secara tidak langsung telah meningkatkan industrialisasi yang pada akhirnya akan meningkatkan jumlah output yang memungkinkan terjadinya peningkatan pada ekspor. Hal ini sejalan dengan penelitian Brenton and Di Mauro (1999), yang menyatakan bahwa secara statistik terdapat hubungan yang positif antara FDI dan ekspor, yakni hubungan komplementer yang kuat.

Dari uraian di atas, penelitian tentang pola perdagangan Provinsi Sumatera Utara ke negara-negara tujuan utama ekspor sangat penting dilakukan untuk mengetahui faktor-faktor apa saja yang mempengaruhi nilai ekspor Provinsi Sumatera Utara terhadap negara-negara mitra dagangnya. Pengetahuan akan determinan ekspor tersebut dapat digunakan untuk mengambil langkah-langkah strategis dalam mengembangkan potensi perdagangan internasional Provinsi Sumatera Utara. Dengan demikian, tujuan penelitian ini adalah adalah untuk menganalisis pengaruh produk domestik bruto per kapita negara importir, pengaruh jumlah populasi negara importir, pengaruh jarak geografis, pengaruh nilai tukar efektif riil, dan pengaruh FDI terhadap nilai ekpor Provinsi Sumatera Utara, dalam kurun waktu 2005-2010. 


\section{METODE PENELITIAN}

Jenis data yang digunakan dalam penelitian ini adalah data panel, yang merupakan gabungan dari data time series dan cross section dari tahun 2005 sampai dengan tahun 2010. Adapun sumber sebagai berikut:

- Data nilai realisasi investasi asing langsung (FDI) Provinsi Sumatera Utara sebagai ekportir diperoleh dari dari BPS Provinsi Sumatera Utara.

- Data data nilai tukar efektif riil diperoleh dari International Monetary Fund dalam Bruegel Working Paper.

- Data negara-negara mitra dagang Sumatera Utara yang merupakan negara tujuan utama ekspor, terdiri dari 10 negara (India, Jepang, Cina, Amerika Serikat, Singapura, Malaysia, Belanda, Mesir, Italia, dan Ukraina), diperoleh dari World Bank (data GDP dan jumlah populasi), International Merchandise Trade Statistics (data nilai total impor), http://www.geobytes.com/ CityDistanceTool.htm. (data jarak geografis).

Adapun model yang akan digunakan dalam penelitian ini adalah:

$$
\begin{aligned}
\ln E X P_{S U j}^{t}= & \beta_{0}+\beta_{1} \ln G D P_{j}^{t}+\beta_{2} \ln P O P_{j}^{t}+\beta_{3} \ln D I S T_{S U j} \\
& +\beta_{4} \ln F D I_{S U}^{t}+\beta_{5} \ln R E E R_{S U}^{t}+\varepsilon_{i t}
\end{aligned}
$$

di mana :

$\begin{array}{lll}\beta_{0} & = & \text { intersep } \\ \beta_{1}, \ldots, \beta_{5} & = & \text { parameter masing-masing variabel } \\ t & = & (1, \ldots, \mathrm{T}) \text { mulai tahun 2005 sampai dengan tahun } 2010 \\ j & = & (1, \ldots ., \mathrm{N}) \text { negara mitra dagang tujuan utama ekspor } \\ S U & = & \text { Sumatera Utara } \\ X_{S U j}^{t} & = & \text { nilai ekspor Sumatera Utara ke negara } j \text { pada tahun } t \\ & = & \text { nuta US\$) } \\ G D P_{j}^{t} & = & \text { jumlah penduduk negara importir } j \text { pada tahun } t \text { (juta } \\ (\mathrm{US} \$) & = & \text { jarak geografis antara ibu kota Sumatera Utara dan ibu } \\ P O P_{j}^{t} & & \text { kota negara importir } j \text { (km) } \\ \text { jiwa) } & =\begin{array}{l}\text { nilai investasi asing langsung di Sumatera Utara pada } \\ D I S T_{S U j}\end{array} & \end{array}$

QE Journal |Vol.02 - No.02 - 41 


$$
\begin{array}{ll}
R E E R_{S U}^{t} & =\text { nilai tukar efektif riil Sumatera Utara pada tahun } t \\
\varepsilon_{i t} & =\text { error term }
\end{array}
$$

Sebagaimana diketahui bahwa data panel dapat dianalisis dengan tiga pilihan yaitu model pooled ordinary least square (PLS), model efek tetap (Fixed Effect Model atau FEM), dan model efek random (Random Effect Model atau REM). Model analisis data yang digunakan pada penelitian ini adalah model efek random (Random Effect Model atau REM), dengan pertimbangan sebagai berikut:

1. Salah satu variabel bebas dalam penelitian ini merupakan data yang tidak berubah terhadap waktu (time-invariant atau time-constant), yakni variabel jarak geografis (DIST). Menurut Wooldridge (2006) dan Kmenta dalam Gujarati (2012), jika dalam data panel terdapat variabel penjelas yang tidak berubah terhadap waktu, maka model yang digunakan adalah model efek random (REM).

2. Menurut Egger (2000), model efek random (REM) baik digunakan untuk melihat aliran perdagangan dengan mitra dagang yang memiliki jumlah populasi yang lebih besar. Dalam penelitian ini, negara-negara mitra dagang tujuan utama ekspor Provinsi Sumatera Utara, memiliki jumlah populasi (jumlah penduduk) yang lebih besar daripada jumlah penduduk Provinsi Sumatera Utara, kecuali negara Singapura.

3. Data yang digunakan dalam penelitian ini adalah data panel pendek, di mana jumlah unit cross-section $(\mathrm{N}=10)$ lebih besar daripada jumlah data time-series ( $\mathrm{T}$ =6). Menurut Gujarati (2012), pada keadaan $\mathrm{N}$ lebih besar daripada $\mathrm{T}$, penggunaan model efek random (REM) akan lebih kuat daripada model efek tetap (FEM).

\section{HASIL DAN PEMBAHASAN}

\section{Perkembangan Ekspor Provinsi Sumatera Utara}

Tabel 4 berikut memperlihatkan perkembangan nilai ekspor Provinsi Sumatera Utara dalam kurun waktu 2005-2010.

Nilai ekspor Provinsi Sumatera Utara pada tahun 2010 mencapai 9.147,778 juta US\$, meningkat dua kali lipat dibandingkan pada tahun 2005 yang hanya sebesar $4.563,075$ juta US\$. Secara keseluruhan, dalam kurun waktu 2005-2010, nilai ekspor Provinsi Sumatera Utara memiliki pertumbuhan rata-rata sebesar 16,50 persen. 
Tabel 4. Perkembangan Nilai Provinsi Sumatera Utara Tahun 2005 - 2010

\begin{tabular}{ccc}
\hline Tahun & Nilai (juta US\$) & Pertumbuhan (\%) \\
$\mathbf{1}$ & $\mathbf{2}$ & $\mathbf{3}$ \\
\hline 2005 & $4.563,075$ & 7,63 \\
2006 & $5.523,901$ & 21,04 \\
2007 & $7.082,899$ & 28,22 \\
2008 & $9.261,977$ & 30,77 \\
2009 & $6.460,117$ & $-30,25$ \\
2010 & $9.147,778$ & 41,60 \\
Total & $\mathbf{4 2 . 0 3 9 , 7 4 7}$ & \\
\hline
\end{tabular}

Sumber : BPS (berbag ai tahun terbitan, diolah)

Sementara itu, seperti ditunjukkan pada Tabel 2 sebelumnya, nilai total ekspor Provinsi Sumatera Utara ke sepuluh negara tujuan utama meliputi 61,68 persen dari nilai total ekspor Provinsi Sumatera Utara dalam kurun waktu 2005-2010. Terlihat bahwa India merupakan negara tujuan ekspor dengan nilai terbesar yakni 22,48 persen, kemudian berturut-turut diikuti oleh Jepang (19,83\%), Cina $(13,89 \%)$, Amerika Serikat (12,43\%), Belanda (8,52\%), Singapura (6,59\%), Malaysia $(6,01 \%)$, Italia $(3,77 \%)$, Mesir (3,69\%), dan Ukraina (2,79\%).

Selama kurun waktu 2005-2010, nilai ekspor Provinsi Sumatera Utara ke masingmasing negara mitra dagang tersebut memiliki rata-rata pertumbuhan yang positif, yakni ke India rata-rata tumbuh sebesar 44,11 persen, ke Mesir rata-rata tumbuh sebesar 39,77 persen, ke Ukraina rata-rata tumbuh sebesar 39,73 persen, ke Italia rata-rata tumbuh sebesar 20,80 persen, ke Cina rata-rata tumbuh sebesar 20,26 persen, ke Malaysia rata-rata tumbuh sebesar 19,52 persen, ke Jepang ratarata tumbuh sebesar 19,32 persen, ke Singapura rata-rata tumbuh sebesar 12,15 persen, ke Belanda rata-rata tumbuh sebesar 11,36 persen, dan ke Amerika Serikat memiliki pertumbuhan rata-rata sebesar 8,88 persen.

Tabel 5 menunjukkan besarnya gross domestic product (GDP), jumlah penduduk, serta GDP per kapita dari masing-masing negara tujuan utama ekspor Provinsi Sumatera Utara. Empat negara dengan GDP terbesar, yakni Amerika Serikat, Jepang, Cina, dan India merupakan negara-negara mitra dagang dengan nilai impor terbesar dari Provinsi Sumatera Utara. Meskipun Italia juga termasuk negara yang memiliki GDP besar, namun nilai impornya dari Provinsi Sumatera Utara relatif kecil, karena jumlah penduduknya yang relatif lebih sedikit dibandingkan dengan keempat negara tersebut di atas. Sedangkan dari besarnya GDP per kapita, dalam kurun waktu 2005-2010, Belanda merupakan negara dengan rata-rata GDP per kapita terbesar yakni 46,049 miliar US\$, disusul oleh Amerika Serikat (45,720 miliar US\$), Jepang (37,405 miliar US\$), Singapura (34,906 miliar US\$), Italia (34,252 miliar US\$), Malaysia (6,909 miliar US\$), Cina (3,007

QE Journal |Vol.02 - No.02 - 43 
miliar US\$), Ukraina (2,769 miliar US\$), Mesir (1,912 miliar US\$) dan India (1,022 miliar US\$). Meskipun Cina dan India memiliki GDP per kapita relatif kecil di antara negara-negara tersebut, namun nilai impornya dari Provinsi Sumatera Utara termasuk yang terbesar karena kedua negara tersebut memiliki jumlah populasi yang besar.

Berdasarkan Tabel 2 dan Tabel 5 di atas, terlihat bahwa negara-negara dengan jumlah penduduk yang relatif lebih besar, yakni India, Jepang, Cina, dan Amerika Serikat, merupakan negara-negara mitra dagang dengan nilai impor terbesar dari Provinsi Sumatera Utara. Hal ini karena jumlah penduduk yang besar merupakan potensi pasar ekspor dari negara eksportir. Dari Tabel 5 terlihat bahwa meskipun Belanda, Singapura, dan Italia termasuk negara-negara dengan GDP per kapita relatif besar, namun karena jumlah penduduknya relatif sedikit, nilai ekspor Provinsi Sumatera Utara ke dua negara tersebut juga relatif kecil.

Dari Gambar 2 sebelumnya, terlihat bahw a dua negara yang memiliki jarak terjauh dari ibu kota Provinsi Sumatera Utara, yakni Belanda $(9.955 \mathrm{~km})$ dan Amerika Serikat $(15.284 \mathrm{~km})$, memiliki nilai impor dari Provinsi Sumatera Utara yang relatif lebih kecil dibandingkan dengan India dan Jepang yang jaraknya lebih dekat, masing-masing $3.594 \mathrm{~km}$ dan $5.527 \mathrm{~km}$. Meskipun Cina memiliki jarak geografis yang lebih dekat dibandingkan dengan Jepang, namun Provinsi Sumatera Utara memiliki nilai ekspor yang lebih besar ke Jepang dibandingkan dengan ke Cina. Menurut Tarmidi (2008), hal ini selain karena usaha diversifikasi besar-besaran terhadap produknya, juga karena sebagian besar produk-produk Cina di pasaran domestiknya dijual dengan harga yang lebih murah. Fenomena ini juga dialami oleh negara-negara lain mitra dagang Cina.

Perkembangan nilai tukar efektif riil Indonesia (2005-2010) ditunjukkan pada Gambar 4, yang memperlihatkan bahwa dalam kurun waktu 2005-2010, indeks nilai tukar efektif riil (REER) Indonesia cukup stabil dan menunjukkan kecenderungan yang positif. Hal ini berarti bahwa tingkat harga umum barangbarang ekspor dari Indonesia relatif lebih murah daripada harga barang-barang yang sama di luar negeri. Faktor ini merupakan salah satu pendorong meningkatnya nilai ekspor Provinsi Sumatera Utara. 
Tabel 5. GDP (miliar US\$), Jumlah Penduduk (juta jiwa), dan GDP per Kapita (miliar US\$) Negara-Negara Tujuan Utama Ekspor Provinsi Sumatera Utara Tahun 2005-2010

\begin{tabular}{|c|c|c|c|c|c|c|c|}
\hline \multirow{2}{*}{\multicolumn{2}{|c|}{$\begin{array}{l}\text { Negara Tujuan } \\
\text { Utama Ekspor }\end{array}$}} & \multicolumn{6}{|c|}{ Ta hun } \\
\hline & & 2005 & 2006 & 2007 & 2008 & 2009 & 2010 \\
\hline & 1 & 2 & 3 & 4 & 5 & 6 & 7 \\
\hline \multirow{3}{*}{$\underset{\Xi}{\overparen{\pi}}$} & GDP & 834,2 & 949,1 & 1238,7 & 1224,1 & 1361,1 & 1684,3 \\
\hline & $\begin{array}{l}\text { Jumlah } \\
\text { penduduk }\end{array}$ & 1140 & 1157 & 1174 & 1190,9 & 1207,7 & 1224,6 \\
\hline & $\begin{array}{l}\text { GDP per } \\
\text { kapita }\end{array}$ & 0,731 & 0,820 & 1,055 & 1,027 & 1,126 & 1,375 \\
\hline \multirow{3}{*}{$\begin{array}{l}\infty \\
\approx \\
\stackrel{0}{0} \\
\stackrel{0}{\varrho}\end{array}$} & GDP & 4571,9 & 4356,7 & 4356,3 & 4849,2 & 5035,1 & 5488,4 \\
\hline & $\begin{array}{l}\text { Jumlah } \\
\text { penduduk }\end{array}$ & 127,8 & 127,8 & 127,8 & 127,7 & 127,6 & 127,5 \\
\hline & $\begin{array}{l}\text { GDP per } \\
\text { kapita }\end{array}$ & 35,774 & 34,089 & 34,087 & 37,973 & 39,460 & 43,046 \\
\hline \multirow{3}{*}{$\stackrel{\widetilde{U}}{\Xi}$} & GDP & 2256,9 & 2712,9 & 3494,1 & 4521,8 & 4991,3 & 5930,5 \\
\hline & $\begin{array}{l}\text { Jumlah } \\
\text { penduduk }\end{array}$ & 1303,7 & 1311 & 1317,9 & 1324,7 & 1331,4 & 1338,3 \\
\hline & $\begin{array}{l}\text { GDP per } \\
\text { kapita }\end{array}$ & 1,731 & 2,069 & 2,651 & 3,413 & 3,749 & 4,431 \\
\hline \multirow{3}{*}{ 必 } & GDP & 12564 & 13315 & 13962 & 14219 & 13864 & 14447 \\
\hline & $\begin{array}{l}\text { Jumlah } \\
\text { penduduk }\end{array}$ & 295,5 & 298,4 & 301,2 & 304,1 & 306,8 & 309,3 \\
\hline & $\begin{array}{l}\text { GDP per } \\
\text { kapita }\end{array}$ & 42,518 & 46,790 & 46,355 & 46,758 & 45,189 & 46.709 \\
\hline \multirow{3}{*}{$\begin{array}{l}\frac{\pi}{\mathbb{Z}} \\
\frac{\mathbb{J}}{\mathbb{D}} \\
\infty\end{array}$} & GDP & 638,5 & 677,7 & 782,6 & 870,8 & 793,4 & 774,2 \\
\hline & $\begin{array}{l}\text { Jumlah } \\
\text { penduduk }\end{array}$ & 16,3 & 16,3 & 16,4 & 16,4 & 16,5 & 16,6 \\
\hline & $\begin{array}{l}\text { GDP per } \\
\text { kapita }\end{array}$ & 39,172 & 41,577 & 47,720 & 53,098 & 48,085 & 46,639 \\
\hline \multirow{3}{*}{ 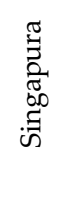 } & GDP & 123,5 & 139,1 & 168,4 & 167 & 175,9 & 213,2 \\
\hline & $\begin{array}{l}\text { Jumlah } \\
\text { penduduk }\end{array}$ & 4,3 & 4,4 & 4,6 & 4,8 & 4,9 & 5,1 \\
\hline & $\begin{array}{l}\text { GDP per } \\
\text { kapita }\end{array}$ & 28,721 & 31,614 & 36,609 & 34,792 & 35,898 & 41,804 \\
\hline \multirow{3}{*}{$\frac{\sqrt[\pi]{0}}{\stackrel{\pi}{\frac{\pi}{\pi}}}$} & GDP & 138 & 156,6 & 186,8 & 222,7 & 192,9 & 237,8 \\
\hline & $\begin{array}{l}\text { Jumlah } \\
\text { penduduk }\end{array}$ & 26,1 & 26,6 & 27,1 & 27,5 & 27,9 & 28,4 \\
\hline & $\begin{array}{l}\text { GDP per } \\
\text { kapita }\end{array}$ & 5,287 & 5,887 & 6,893 & 8,098 & 6,914 & 8,373 \\
\hline \multicolumn{2}{|c|}{$\sigma \neg \cdot$} & 1786,3 & 1873 & 2127,2 & 2307,3 & 2111,1 & 2043,6 \\
\hline
\end{tabular}

QE Journal |Vol.02 - No.02 - 45 


\begin{tabular}{|c|c|c|c|c|c|c|c|}
\hline & $\begin{array}{c}\text { GDP } \\
\text { Jumlah } \\
\text { penduduk }\end{array}$ & 58,6 & 58,9 & 59,4 & 59,8 & 60,2 & 60,5 \\
\hline & $\begin{array}{l}\text { GDP per } \\
\text { kapita }\end{array}$ & 30,479 & 31,777 & 35,826 & 38,569 & 35,073 & 33,789 \\
\hline \multirow{3}{*}{$\stackrel{0}{0}^{: 0}$} & GDP & 89,7 & 107,5 & 130,5 & 162,8 & 189 & 218,9 \\
\hline & $\begin{array}{c}\text { Jumlah } \\
\text { penduduk }\end{array}$ & 74,2 & 75,6 & 76,9 & 78,3 & 79,7 & 81,1 \\
\hline & $\begin{array}{l}\text { GDP per } \\
\text { kapita }\end{array}$ & 1,208 & 1,422 & 1,696 & 2,079 & 2,371 & 2,698 \\
\hline \multirow{3}{*}{ 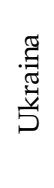 } & GDP & 86,1 & 107,8 & 142,7 & 179,9 & 117,2 & 136,4 \\
\hline & $\begin{array}{l}\text { Jumlah } \\
\text { penduduk }\end{array}$ & 47,1 & 46,8 & 46,5 & 46,3 & 46,1 & 45,9 \\
\hline & $\begin{array}{l}\text { GDP per } \\
\text { kapita }\end{array}$ & 1,829 & 2,303 & 3,069 & 3,891 & 2,545 & 2,974 \\
\hline
\end{tabular}

Sumber: World Bank(diolah)

Secara empiris, dalam kurun waktu 2005-2010, pertumbuhan FDI tidak selalu bersifat komplementer dengan pertumbuhan nilai total ekspor di Provinsi Sumatera Utara, seperti terlihat pada Gambar 1.

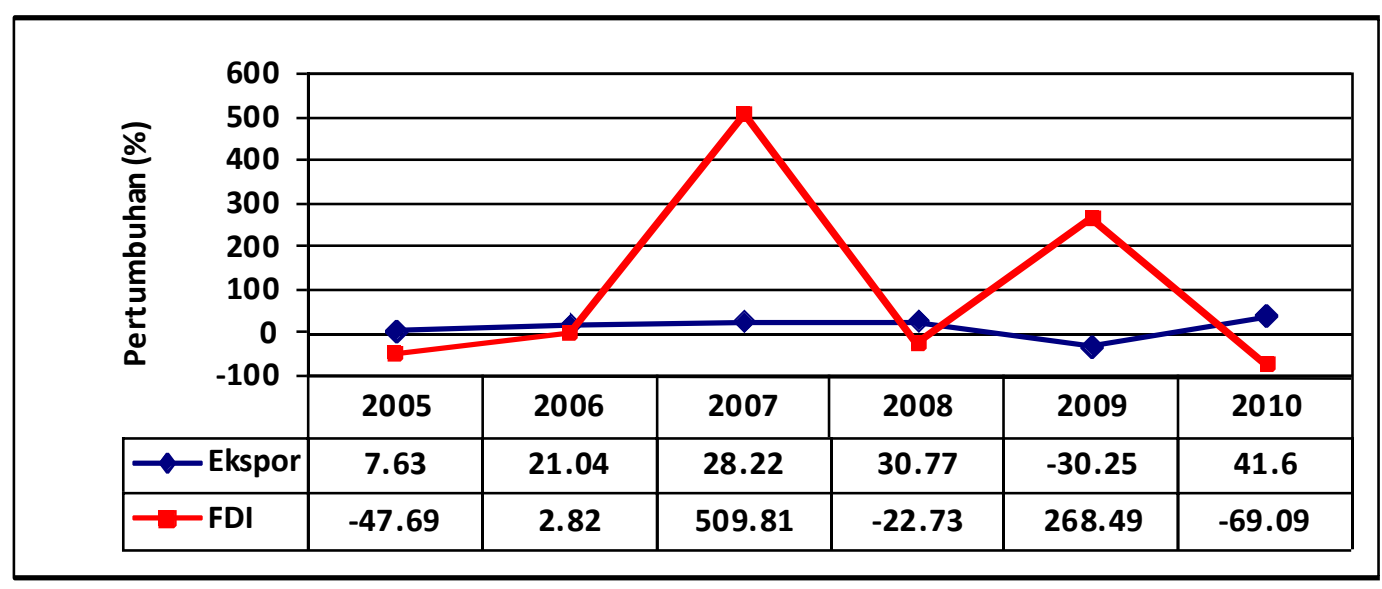

Sumber: BPS (2011, diolah)

Gambar 1. Pertumbuhan FDI dan Nilai Total Ekspor ProvinsiSumatera UtaraTahun 2005-2010

Dari Gambar 1 di atas, terlihat bahwa pada tahun-tahun tertentu, peningkatan (penurunan) FDI tidak selalu diikuti oleh peningkatan (penurunan) nilai ekspor total Provinsi Sumatera Utara. Pada tahun 2006 dan 2007, peningkatan FDI diikuti oleh peningkatan nilai total ekspor Provinsi Sumatera Utara.

QE Journal | Vol.02 - No.02 - 46 
Namun, pada tahun 2005, 2008, 2009, dan 2010, peningkatan (penurunan) FDI justru diikuti dengan penurunan (peningkatan) nilai total ekspor Provinsi Sumatera Utara.

Setelah dilakukan pengolahan data panel dengan bantuan program Eviews4.1., maka diperoleh hasil sebagaimana ditunjukkan pada Tabel 6 berikut:

Tabel 6. Hasil Analisis Data Panel dengan Random Effect Model

Dependent V ariable: LNEXP?

Method: GLS (V ariance Components)

Date: 02/06/13 Time: 10:26

Sample: 20052010

Included observations: 6

Number of cross-sections used: 10

Total panel (balanced) observations: 60

\begin{tabular}{|c|c|c|c|c|}
\hline Variable & Coefficient & Std. Error & $\mathrm{t}-\mathrm{S}$ tatistic & Prob. \\
\hline C & -4.340974 & 3.005439 & -1.444373 & 0.1544 \\
\hline LNGDPJ? & 0.475563 & 0.146134 & 3.254303 & 0.0020 \\
\hline LNPOPJ? & 0.526684 & 0.146149 & 3.603757 & 0.0007 \\
\hline LNDIST? & -0.353462 & 0.190536 & -1.855087 & 0.0690 \\
\hline LNFDI? & 0.116408 & 0.043342 & 2.685806 & 0.0096 \\
\hline LNREER? & 1.247364 & 0.603444 & 2.067074 & 0.0435 \\
\hline \multicolumn{5}{|l|}{ Random Effects } \\
\hline _INDIA-C & 0.593830 & & & \\
\hline JAPAN-C & 0.214817 & & & \\
\hline _CINA-C & -0.212421 & & & \\
\hline _USA-C & -0.396800 & & & \\
\hline SSING-C & 0.134081 & & & \\
\hline _MALAY-C & -0.331068 & & & \\
\hline _NETH-C & 0.554933 & & & \\
\hline _MESIR-C & 0.219412 & & & \\
\hline _ITALY-C & -0.796172 & & & \\
\hline UKRAINA-C & 0.019387 & & & \\
\hline \multicolumn{5}{|l|}{$\begin{array}{l}\text { GLS Transformed } \\
\text { Regression }\end{array}$} \\
\hline R-squared & 0.872111 & Mean depen & & 5.771003 \\
\hline Adjusted R-squared & 0.860269 & S.D. depend & & 0.821188 \\
\hline S.E. of regression & 0.306965 & Sum squared & & 5.088280 \\
\hline Durbin-Watson stat & 1.518231 & & & \\
\hline \multicolumn{5}{|l|}{$\begin{array}{c}\text { UnweightedStatistics } \\
\text { including Random Effects }\end{array}$} \\
\hline R-squared & 0.883002 & Mean depen & & 5.771003 \\
\hline Adjusted R-squared & 0.872169 & S.D. depend & & 0.821188 \\
\hline S.E. of regression & 0.293604 & Sum squared & & 4.654966 \\
\hline Durbin-Watson stat & 1.659557 & & & \\
\hline
\end{tabular}

QE Journal | Vol.02 - No.02 - 47 
Dari hasil estimasi model penelitian yang telah diuji, diperoleh bahwa nilai ekspor Provinsi Sumatera Utara dipengaruhi oleh beberapa faktor yaitu nilai produk domestik bruto per kapita negara tujuan ekspor, jumlah penduduk negara tujuan ekspor, jarak geografis, nilai investasi asing langsung atau foreign direct investment (FDI) di Provinsi Sumatera Utara, dan nilai tukar efektif riil Provinsi Sumatera Utara.

Jika nilai produk domestik bruto per kapita suatu negara tujuan ekspor meningkat sebesar satu persen maka nilai ekspor Provinsi Sumatera Utara ke negara tersebut akan meningkat sebesar 0,48 persen. Hal ini sesuai dengan teori ekonomi yang menyatakan bahwa impor suatu negara sangat berhubungan dengan pendapatan nasional negara tersebut, di mana semakin tinggi pendapatan maka semakin tinggi pula kemampuan negara tersebut melakukan impor dari negara lain(Sukirno,2006; Boediono,2008).Hasil ini juga sejalan dengan penelitian yang dilakukan oleh Amita Batra (2004), Franscesca Di Mauro (2000), serta Elliot and Ikemoto (2005).

Jika jumlah penduduk (POP) suatu negara tujuan ekspor meningkat sebesar satu persen maka nilai ekspor Provinsi Sumatera Utara ke negara tersebut akan meningkat sebesar 0,53 persen. Hal ini membuktikan bahwa jumlah populasi negara importir menunjukkan potensi pasar produk ekspor. Hasil ini sejalan dengan penelitian yang dilakukan oleh Elliot and Ikemoto (2005).

Jika jarak geografis (DIST) antara ibu kota Provinsi Sumatera Utara dan ibu kota suatu negara tujuan ekspor meningkat sebesar satu persen maka nilai ekspor Provinsi Sumatera Utara ke negara tersebut akan menurun sebesar 0,35 persen. Hal ini sesuai dengan teori yang dikemukakan oleh Krugman (1991) bahwa jarak merupakan hambatan dalam perdagangan. Menurut Head (2003), selain sebagai proksi atas biaya transportasi, jarak juga menggambarkan berbagai biaya lainnya seperti biaya komunikasi, biaya atas waktu yang hilang selama pengiriman, biaya untuk mencari peluang perdagangan, biaya sinkronisasi, bahkan biaya budaya. Berbagai penelitian empiris telah membuktikan hal tersebut, seperti penelitian yang dilakukan oleh Amita Batra (2004), Franscesca Di Mauro (2000), serta Elliot and Ikemoto (2005).

Meskipun hasil penelitian menunjukkan bahwa secara umum jarak geografis berpengaruh negatif dan signifikan terhadap nilai ekspor Provinsi Sumatera Utara, namun terlihat fenomena berupa penyimpangan jika dibandingkan dengan data riil, yaitu nilai ekspor Provinsi Sumatera Utara ke Malaysia dan Singapura - yang merupakan negara tetangga terdekat - justru lebih rendah dibandingkan dengan nilai ekspor Provinsi Sumatera Utara ke negara-negara lainnya yang secara geografis lebih jauh. Fenomena ini kemungkinan disebabkan karena banyaknya kesamaan produk komoditas ekspor di antara negara-negara anggota ASEAN. Misalnya, CPO (crude palm oil) yang merupakan salah satu produk unggulan 
ekspor Provinsi Sumatera Utara, juga merupakan produk unggulan ekspor Malaysia. Demikian juga dengan ekspor karet alam, kemungkinan tidak terlalu dipengaruhi oleh jarak; hal ini diduga ada kaitanny a dengan praktik perdagangan karet alam di mana transaksi perdagangan banyak terjadi di bursa komoditi di Singapura dan New York, akibatnya sekalipun Provinsi Sumatera Utara merupakan salah satu produsen terbesar karet alam, namun bukan sebagai trader sehingga tidak mampu mempengaruhi harga internasional.

Selanjutnya, jika nilai investasi asing langsung atau foreign direct investment (FDI) di Provinsi Sumatera Utara meningkat satu persen maka nilai ekspor Provinsi Sumatera Utara ke negara mitra dagangnya akan meningkat sebesar 0,12 persen. Hasil ini sesuai dengan teori yang dikemukakan oleh Krugman (1991) bahwa di negara-negara berkembang, investasi asing langsung telah menjadi pendorong tumbuhnya industrialisasi yang berorientasi ekspor. Hal ini telah dibuktikan secara empiris dengan penelitianSanti Chaisrisaw atsuk dan Wisit Chaisrisaw atsuk (2007), di mana ekspor dan FDI merupakan variabel komplementer.

Demikian juga, jika nilai tukar efektif riil (REER) mengalami peningkatan sebesar satu persen maka nilai ekspor Provinsi Sumatera Utara ke negara mitra dagangnya akan meningkat sebesar 1,25 persen. Hal ini sesuai dengan teori ekonomi bahwa peningkatan nilai tukar efektif riil (rupiah mengalami depresiasi) akan mendorong meningkatnya ekspor. Sebaliknya nilai tukar efektif riil yang rendah (rupiah mengalami apresiasi) akan menyebabkan penurunan ekspor. Hasil ini didukung oleh dengan penelitian yang dilakukan oleh Sarwedi (2010).

Hasil estimasi model penelitian juga menunjukkan bahwa rerata nilai komponen kejutan acak (error term) dari cross-section negara mitra dagang $(\mathrm{N}=10$ negara) adalah sebesar negatif 4,340974. Sedangkan nilai pengaruh acak (random effect) terbesar adalah negara India sebesar 0,593830, kemudian diikuti berturut-turut oleh negara Belanda $(0,554933)$, Mesir $(0,219412)$, Jepang $(0,214817)$, Singapura $(0,134081)$, Ukraina $(0,019387)$, Cina $(-0,212421)$, Malaysia $(-0,331068)$, Amerika Serikat $(-0,396800)$, dan Italia $(-0,796172)$. Komponen error ini adalah unobservable atau tidak dapat diamati, yang mencerminkan berbagai faktor lain yang tidak dapat diterangkan oleh kelima variabel bebas dalam penelitian ini, misalnya kebijakan-kebijakan yang menghambat perdagangan bilateral, baik hambatan tarif, hambatan nontarif, ataupun kebijakan nonekonomi.

Dari hasil estimasi terlihat bahwa aliran ekspor ke India memiliki hambatan yang paling sedikit, disusul berturut-turut oleh Belanda, Mesir, Jepang, Singapura, Ukraina, Cina, Malay sia, Amerika Serikat, dan Italia.

QE Journal |Vol.02 - No.02 - 49 


\section{SIMPULAN DAN SARAN}

\section{Kesimpulan}

Dari hasil estimasi penelitian dan pembahasan seperti telah diuraikan pada bab sebelumnya, pendekatan gravity model mampu menjelaskan determinan ekspor Provinsi Sumatera Utara dalam kurun waktu 2005-2010. Adapun kesimpulan dari penelitian ini sebagai berikut:

1. Variabel produk domestik bruto per kapita dari masing-masing negara tujuan utama ekspor Provinsi Sumatera Utara berpengaruh positif secara signifikan terhadap nilai ekspor Provinsi Sumatera Utara, sehingga jika nilai produk domestik bruto negara tujuan ekspor meningkat satu persen, maka nilai ekspor Provinsi Sumatera Utara akan meningkat sebesar 0,48 persen.

2. Variabel jumlah penduduk dari masing-masing negara tujuan utama ekspor Provinsi Sumatera Utara berpengaruh positif secara signifikan terhadap nilai ekspor Provinsi Sumatera Utara, sehingga jika jumlah penduduk negara tujuan ekspor meningkat satu persen, maka nilai ekspor Provinsi Sumatera Utara akan meningkat sebesar 0,53 persen.

3. Variabel jarak geografis antara ibu kota Provinsi Sumatera Utara dan ibu kota masing-masing negara tujuan utama ekspor Provinsi Sumatera Utara secara umum berpengaruh negatif dan signifikan, di mana peningkatan satu persen dalam jarak akan menurunkan nilai ekspor Provinsi Sumatera Utara sebesar 0,35 persen. Namun demikian, untuk dua negara tujuan ekspor yakni Malaysia dan Singapura, terlihat fenomena tersendiri di mana pengaruh jarak geografis tidak sesuai dengan keadaan riil. Hal ini terkait dengan komoditas unggulan yang dipengaruhi oleh faktor kesamaan produk serta proses transaksi perdagangan komoditas tersebut.

4. Variabel investasi asing langsung atau foreign direct investment di Provinsi Sumatera Utara berpengaruh positif secara signifikan terhadap nilai ekspor Provinsi Sumatera Utara, sehingga jika investasi asing langsung meningkat satu persen, maka nilai ekspor Provinsi Sumatera Utara akan meningkat sebesar 0,12 persen.

5. Variabel nilai tukar efektif riil (REER) berpengaruh positif secara signifikan terhadap nilai ekspor Provinsi Sumatera Utara, di mana peningkatan REER sebesar satu persen akan meningkatkan nilai ekspor Provinsi Sumatera Utara sebesar 1,25 persen.

QE Journal |Vol.02 - No.02 - 50 


\section{Saran}

1. Kebijakan-kebijakan pemerintah hendaknya dapat mendorong pertumbuhan investasi asing langsung di Provinsi Sumatera Utara, khususnya yang berorientasi ekspor, karena terbukti bahwa pertumbuhan FDI dapat meningkatkan nilai ekspor Provinsi Sumatera Utara.

2. Bank Indonesia hendaknya tetap memperhatikan kebijakan terhadap kestabilan nilai tukar rupiah, karena terbukti bahwa nilai tukar efektif riil sangat berpengaruh terhadap nilai ekspor Provinsi Sumatera Utara.

3. Untuk mendapatkan hasil yang lebih komprehensif atas faktor-faktor yang mempengaruhi ekspor Provinsi Sumatera Utara, bagi yang berminat hendaknya melakukan penelitian terhadap berbagai komoditas unggulan ekspor serta memasukkan variabel lain seperti keterlibatan dalam perjanjian perdagangan atau integrasi ekonomi (misalnya AFTA, APEC, dan lain-lain) dan variabel relevan lainnya. Selain itu, jika penelitian dilakukan untuk tiap komoditas, maka dapat memakai variabel biaya transportasi tanpa harus diproksi dengan jarak geografis.

\section{DAFTAR PUSTAKA}

Badan Pusat Statistik. Berbagai tahun terbitan. Sumatera Utara Dalam Angka. Medan: BPS.

Batra, Amita. 2004. India's Global Trade Potential: The Gravity Model Approach. Working Paper No.151. New Delhi: ICRIER.

Boediono. 2008. Ekonomi Makro (edisi keempat). Yogyakarta: BPFE.

Brenton, P., and Di Mauro, F. 1999. The Potential Magnitude and Impact of FDI Flow to CEECs. Journal of Economic Integration, Vol. 14 No. 1, pp 59-74.

Chaisrisaw atsuk, S. \& W. Chaisrisaw atsuk. 2007. Imports, Exports and Foreign Direct Investment Interactions and Their Effects. Towards Coherent Policy Frameworks: Understanding Trade and Investment Linkages - A study by the Asia-Pacific Research and Training Network on Trade, pp.93-110. New York: United Nations.

Di Mauro, Fransesca. 2000. The Impact of Economic Integration on FDI and Export: A Gravity Approach. CEPS Working Document No.156.

Egger, P. 2000. A Note on the Proper Econometric Specification of the Gravity Equation. Economic Letter 66, 25-31.

Elliot, Robert J.R., Kengo Ikemoto. 2005. AFTA and Asian Crisis: Help or Hidrance to ASEAN Intra-Regional Trade? (online) (www.lesmanac.uk/ses/research/discussion-paper0311.pdf., diakses 12 Oktober 2012).

Gujarati, Damodar N. 2012. Dasar-Dasar Ekonometrika (Buku 2, edisi ke-5). Jakarta: Salemba Empat.

QE Journal |Vol.02 - No.02 - 51 
Head, Keith. 2003. Gravity for Beginners. Vancounver: Faculty of Commerce University of British Columbia.

Hoftyzer, J. 1984. A Further Analysis of the Linder Trade Thesis. Quarterly Review of Economics and Bussiness, 24(2), 57-90.

Krugman, Paul R. and Obstfeld, Maurice. 1991. Ekonomi Internasional Teori dan Kebijakan (edisi kedua). Jakarta: P.T. Raja Grafindo Persada.

Samuelson, Paul A., Nordhaus, William D. 1998. Economics (16th edition). USA: The McGraw-Hill Companies, Inc.

Sarwedi. 2010. Analisis Determinan Perubahan Penawaran Barang Ekspor Indonesia. Buletin Ekonomi Moneter dan Perbankan, Vol.12 No.3, Januari 2010. Jakarta: Bank Indonesia.

Sukirno, Sadono. 2006. Makroekonomi Teori Pengantar (edisi ke-3). Jakarta: PT.Raja Grafindo Persada.

Tambunan, Tulus. 2000. Perdagangan Internasional dan Neraca Pembayaran: Teori dan Temuan Empiris. Jakarta: LP3ES.

Tarmidi, L.T., P. Gammeltoft. 2008. "The Characteristics of China's Multinationals in the Manufacturing Sector Operating in Indonesia", Makalah pada Conference "Emerging Multinationals": Outward Foreign Direct Investment from Emerging and Developing Economies", diselenggarakan oleh Copenhagen Business School, Copenhagen, 9-10 Oktober.

Wooldridge, J.M. 2006. Introductory Econometrics: A Modern Approach (4th edition). USA: South-Western Cengage Learning. 